\title{
ORDEM PÚBLICA - PRESCRIÇÃO - DIREITO COMPARADO
}

\section{PARECER}

\section{CONSULTA}

Sou consultado pelo Banco do Brasil com relação a uma execução de título extrajudicial que se processa no foro de Belo Horizonte movida por referida sociedade de economia mista contra empresas e pessoas físicas domiciliadas naquela capital.

1 Sancionado, deu lugar à Lei Complementar $n^{\circ} 108$, de 29.05.01. 
Os executados ofereceram Embargos à Execução nos quais sustentaram a prescrição da dívida pelo decurso do prazo de três anos estabelecido na Lei Uniforme aprovada pela Convenção de Genebra de 1930.

A Exequiente se fundamenta na lei novaiorquina, local da assinatura dos títulos cambiários, que rege a relação jurídica entre as partes e que estabelece o prazo prescricional de seis anos.

Os executados estão de acordo que a lei novaiorquina rege a relação entre credora $e$ devedores, mas sustentam a inaplicabilidade do prazo prescricional da lei estrangeira, por ser este atentatório à ordem pública brasileira e, conseqüentemente, inaplicável por força do artigo 17 da Lei de Introdução ao código civil brasileiro.

Em apoio à sua tese os executados juntam aos autos um parecer do ilustre Professor Humberto Theodoro Junior, no qual sustenta que o prazo prescricional é matéria de ordem pública e acrescenta que sendo a prescrição qualificada em Nova York como matéria processual, não há como aplicá-la no Brasil, onde prescrição é matéria de natureza substantiva.

$O$ respeitado processualista conclui seu parecer da seguinte forma:

"De qualquer forma, a lei relativa à prescrição cambiária americana não deve ser observada no Brasil. Em primeiro lugar porque envolve matéria de ordem pública e, em segundo lugar, por se tratar, na origem, de regra processual e não substancial.

Diante do exposto, respondo à indagação do ilustre consulente afirmando que as regras brasileiras sobre prescrição cambiária devem prevalecer sobre as estrangeiras, sempre que entre ambas houver conflito, por força da regra do art. $17 \mathrm{da} \mathrm{LICC".}$

\section{PARECER}

\section{I}

\section{ORDEM PÚBLICA INTERNA E ORDEM PÚBLICA INTERNACIONAL}

O aspecto central da análise apresentada pelo Professor Humberto Theodoro Junior so- bre a ordem pública é de que "não há qualquer distinção entre ordem pública interna ou internacional". Daí acrescenta que "a observância à ordem social impõe-se tanto aos nacionais, como aos estrangeiros, na disciplina das relações internacionais e deve ser interpretada como um limite à aplicação da lei estrangeira".

O ilustre parecerista invoca um trecho de Maria Helena Diniz e cita a lição do mestre Amilcar de Castro que por sua vez se referia à opinião do Professor Gama e Silva.

A dicotomia ordem pública interna $x$ ordem pública internacional foi objeto de muita discussão na literatura clássica do direito internacional privado até se ter chegado a uma posição consensual nos dias atuais. Há, portanto, necessidade de um ligeiro escorço histórico.

Apesar da distinção entre a ordem pública no direito civil e no direito internacional privado ter sido tratada em primeiro lugar por Paolo Esperson, conforme atesta Charles Knapp em "La Notion de l' Ordre Public dans les Conflits de Lois", p. 33, a idéia é atribuída pelos autores a Charles Brocher, em seu "Cours de Droit International Privé suivant les principes consacrés par le droit positif français", três volumes, 1882-1885.

Brocher elaborou sua tese sobre dois dispositivos do código civil francês, o artigo $3^{\circ}$, alínea 1 e o artigo $6^{\circ}$ : o primeiro dispõe que "les lois de police el de sûreté obligent tous ceux qui habitent le territoire" e o segundo determina que "on ne peut déroger, par des conventions particulières, aux lois qui intéressent l'ordre public el les bonnes moeurs". $\mathrm{Na}$ tradução de Souza Diniz: Artigo $3^{\circ}-1$ — "As leis de polícia e de segurança obrigam todos os que habitam o território". Artigo $6^{\circ}$ - Não se podem derrogar, por convenções particulares, as leis que interessam à ordem pública ou aos bons costumes". O autor interpreta os dois dispositivos como se destinando o artigo $6^{\circ}$ à ordem pública interna e a primeira alínea do artigo $3^{\circ}$ à ordem pública internacional. (Charles Brocher, op. cit., $1^{\circ}$ volume, p. 106-108).

A rigor, Brocher não defendeu a idéia de duas ordens públicas realmente distintas pois 
no mesmo local afirma que os mesmos elementos se encontram nas duas, só que uma "se desenvolve no selo de uma única e mesma legislação, enquanto que a outra traça sua atuação entre soberanias diversas" (op. cit., p. 109). Mas a doutrina francesa evoluiu a ponto de efetivamente aceitar a idéia de duas ordens públicas distintas como se vê em Franz Despagnet que publicou um artigo dedicado à ordem pública, " $L$ 'Ordre Public en droit international privé", no Journal de Droit International, 1889, pp. 5 a 21 e 207 a 222, André Weiss em seu "Traité Théoríque et Pratique de Droit International Prive", volume III, p. 97 (obra em seis volumes, 19071913) e René Foignet, “Manuel Élémentaire de Droit International Privê", 1901, p. 192.

Assim, a dicotomia da ordem pública era geralmente aceita naquela fase de grande desenvolvimento do direito internacional privado, final do século XIX, início do século XX. A reação veio de um dos grande mestres da disciplina, o Professor Antoine Pillet em estudo intitulado, "De l'ordre public en Droit Internalional Privê", publicado no segundo tomo dos "Annales de l'Enseignment supérieur de Grenoble" em 1890, à p. 94 e seguintes e que se tornou mais conhecido quando republicado, em 1929, nos “Melanges Antoine Pillet”, à p. 407 e seguintes, já tendo também sido objeto de sua apreciação no capítulo XIII de "Principes de Droit International Privê" (1903) p. 367 e seguintes.

Nestes trabalhos, Pillet demonstrou a impossibilidade de se conceber duas ordens públicas diferentes, pois o Estado só pode ter uma ordem pública. A doutrina francesa $\mathbf{e}$ italiana acompanharam este entendimento, podendo ser citados Pasquale Fiore, em obra traduzida para o francês, "Le Droit International Privé", tomo I, 1890, p. 274, Vareilles Sommières, "La Synthèse du Droit International Privê", tomo I, 1897, p. 103, Jules Valery, “Manuel de Droit International Privé, 1914, p. 576, Louis Lucas, “Remarques sur l'ordre public" na Revue de Droit International Privê', 1933, p. 392, J.P. Niboyet, "Cours de Droit International Privé Français", 1949, p. 488, René Savatier, "Cours de Droit International Privê,, 1947, p. 218,
P. Arminjon, "Précis de Droit International Privê", tomo I, 1947, p. 221, Charles Knapp, "La Notion de L'Ordre Public dans les Conflits de Lois", 1933, p.82.

$\mathrm{E}$, finalmente, chegamos ao moderno direito internacional privado francês, na obra, sempre atualizada de Henri Batiffol e Paul Lagarde. Ali fica consolidado o entendimento correto sobre a ordem pública nos planos do direito interno e do direito internacional. A ordem pública é efetivamente uma, mas ela tem uma aplicação no âmbito do direito civil interno e outra aplicação no âmbito do direito internacional privado (Batiffol e Lagarde, Droit International Privé, $7^{\mathbf{a}}$ ed., 1981, p. 424)

No Brasil a natureza desta distinção foi bem acolhida pela doutrina. Wilson de Souza Campos Batalha em seu "Tratado Elementar de Direito Internacional Privado", volume II, p.438 se refere a "errônea dicotomia" e acompanha Emilio Betti que, ao invés da expressão ordem pública intemacional, sugere ordem pública interna de relevância internacional" (p. 440). Amilcar de Castro, jusintemacionalista da preferência do ilustre parecerista dos Embargantes, Professor Humberto Theodoro Jr., colocou o tema de forma simples e clara. Diz o mestre mineiro:

"A ordem social ou ordem pública, entretanto, considerada em si mesma é una e indivisível, mas como pode ser agredida de dois modos, por ataques provenientes de situações diversas, é sempre defendida por duas formas. A terminologia empregada por Brocher deu lugar a supor-se haver duas espécies de ordem pública, quando isto é inconcebível. Diferença se encontra nos meios de defesa da ordem pública, não nesta em si mesma que não pode deixar de ser uma só, sempre original, impar e indivisível, porque todas as manifestações sociais que a compõem se influenciam reciprocamente, como acima foi demonstrado",

Um autor brasileiro que estudou o tema da ordem pública, Luiz Araújo Correa de Brito, em " Do limite à exterritorialidade do direito estrangeiro no código civil brasileiro" esclareceu que a fonte de onde promana a ordem pública é sempre nacional, podendo, contudo, haver duplicidade de efeitos. Em suas palavras, à pp. 118-119: 
“Una e única, com relação à fonte geradora ou ao órgão elaborador; dual ou dupla, no que tange aos efeitos de sua aplicação ou incidência"

A posição que vamos expor aqui é a que temos defendido, no plano acadêmico, há vinte e sete anos, em diversos trabalhos, principalmente em "Repercussão do Fundo Monetário Internacional no Direito Internacional Privado" (tese de livre docência para a Universidade da Faculdade de Direito da (então) Universidade do Estado da Guanabara, 1972), em "A Evolução da Ordem Pública no Direito Internacional Privado" (tese à cátedra de Direito Internacional Privado da Universidade do Estado do Rio de Janeiro, 1979) e em "Direito Internacional Privado - Parte Geral, 5 edições.

$\mathrm{Na}$ primeira das obras citadas dissemos, à p. 136:

"Este o ponto que desejamos frisar. A distinção da ordem pública em interna e internacional visa mostrar como a ordem pública se defende de ataques de fontes diversas. Mas a ordem pública é a mesma, é ordem pública interna, nacional. A divisão é mais no plano dos efeitos. Uma dirige-se no plano interno do direito civil, defende a ordem pública da vontade das partes, contratualmente manifestada, a outra vai além, e, na defesa da mesma ordem pública interna, barra a entrada das normas, vontades e sentenças estrangeiras".

$\mathrm{Na}$ segunda tese expressamos o seguinte pensamento, à pp. 40/41:

“Existe o princípio da ordem pública, algo abstrato que é aplicado às leis quando o juiz entender que determinada regra jurídica deve contar com a proteção, com o reforço deste princípio.

E este princípio tem aplicações em vários níveis. Em sua gradação inicial, mais tênue, serve para garantir o império de determinadas regras contra a vontade das partes.

A ordem pública comanda a aplicação da norma jurídica, o direito positivo, não admitindo que as partes optem por outra solução. Todavia, se por força das regras de conexão do direito internacional privado, deva ser aplicada norma de outro país, diversa da nacional, a ordem pública não interferirá.
Em determinadas outras questōes, mais delicadas, em que o aplicador da lei entenda que a ordem pública não admite o emprego de uma lei estrangeira aplicável segundo o DIP, terá que rejeitá-la e procurar outra solução. As regras de conexão do Direito Internacional Privado têm seu efeito paralizado sempre que se entender que a ordem pública impede a aplicação de normas estranhas, por lhe serem chocantes, perturbadoras. Este é o segundo grau da ordem pública.

Esta ordem publica que nega aplicação a determinada norma legal estrangeira que the seja chocante, poderá, todavia, tolerar o reconhecimento de uma situação adquirida no exterior com base nesta mesma norma estrangeira, porque, após consumada a situação, o seu mero reconhecimento não tem a mesma gravidade e não perturba a ordem pública. Mas, poderá haver um instituto estrangeiro tão chocante e que com tamanha intensidade represente um escândalo para o foro, que a sua ordem pública não admita sequer reconhecer uma situação já constituída e consumada.

Este é o terceiro e mais elevado grau do princípio da ordem pública".

Entenda-se, pois, que realmente a ordem pública de cada Estado soberano é uma só, mas seus efeitos não podem ser os mesmos no plano interno e no plano internacional. Ilustrativamente, admitamos que um menino ou menina de 17 anos compareça perante um Tabelião de Notas de Belo Horizonte, e revelando inusitada maturidade intelectual e equilíbrio emocional, peça ao Oficial que redija uma escritura de autoemancipação pela qual o Outorgante/Outorgado, sentindo-se apto para todos os atos da vida civil e comercial se auto-declare plenamente capaz para o exercício de todos os atos jurídicos. É de elementar sabença que o Tabelião se recusará a praticar o ato solicitado, pois as regras do código civil brasileiro sobre a menoridade visam a proteção daqueles que considera menores e incapazes e a vontade da parte não pode contraditar aquelas normas. A ordem pública, característica das leis protetoras, não permitirá a pretendida auto- emancipação.

No entanto, se aparecer no Brasil um me- 
nino ou menina de 17 anos de idade, domiciliado em país que concede plena capacidade aos jovens desta idade, para todos os efeitos civis e comerciais, desejando aqui, em nosso território, vender um imóvel que herdou de seu avô, sua capacidade será por nós reconhecida, pois a maioridade aos 17 anos não é algo que nos choque a ponto de não aceitarmos aplicar uma lei estrangeira, em obediência ao artigo $7^{\circ}$ da Lei de Introdução ao Código Civil que conecta a capacidade civil à lei do país do domicílio da pessoa física.

Todavia, se vier um menino ou menina de 13 anos de idade, domiciliado em um país que Ihe atribui capacidade jurídica nesta idade, nós não aceitaremos aplicar esta lei, porque este limite de idade para aquisição de capacidade é para nós um exagero e chocante à ordem pública brasileira.

Por conseguinte, temos uma ordem pública, é verdade, mas com aplicaçōes diversificadas, distinta a aplicação desta ordem pública no plano interno e no plano intemacional. No plano interno a ordem pública se aplica a um leque grande de situações, enquanto que no plano internacional é mais reduzido o seu raio de ação, e assim, inúmeras situações em que a vontade das partes não prevalece porque contrárias à ordem pública, serão aceitas se decorrentes de aplicação da lei estrangeira. Em outras palavras, há inúmeras situações aceitas em decorrência da aplicação da lei estrangeira, mas que a vontade das partes não poderia produzir no plano interno,

Esta foi a orientação de Haroldo Valladão, conforme se depreende do primeiro volume de sua obra "Direito Internacional Privado", p. 494 da 5" edição, de 1980,onde escreve:

"A conclusão a tirar desse exame de textos vigentes acerca da ordem pública é a confirmação dos pontos de vista doutrinários que procuram, quer caracterizá-la como um limite, excepcional, que reduz a aplicação da lei estrangeira, quer como um grau superior de ordem pública, autônomo (externa) própria do DIP, diversa da ordem pública clássica, do direito comum, civil etc. (interna) que restringe a liberdade individual, opõe-se a certas disposições ou convenções dos particulares;
E a melhor indicação de seu entendimento é a forma como Valladão colocou o tema da ordem pública no seu Projeto de Lei de Aplicação das Normas Jurídicas. No artigo 12 se lê:

"Ordem pública - Não terão eficácia quaisquer declarações de vontade que visem a modificar a constituição da família ou que ofenderem a soberania nacional, a ordem pública, a equiidade, a moral e os bons costumes".

E no artigo 79 encontramos:

"Limite geral da ordem pública e adaptação - As leis, atos e sentenças de outro país, bem como quaisquer declarações de vontade ali formuladas, não terão eficácia no Brasil quando ofenderem a soberania nacional, a ordem pública, a equiidade, a moral ou os bons costumes".

Uma ordem pública, dois efeitos. Um conceito, duas aplicações- Uma noção, duas extensões. Um princípio, duas práticas.

Assim sendo, apesar de ter o Prof. Humberto Theodoro Jr. se mantido fiel à noção de uma ordem pública, não reconheceu em seu parecer que ela tem consequiências diversas no plano interno e no plano internacional. Diz à quarta página de sua respeitável opinião que:

"Não há qualquer distinção entre ordem pública interna ou internacional (nosso grifo).

E logo adiante o nobre parecerista frisa:

"De fato, vendo-se a locução 'ordem pública' como sinônimo perfeito de ordem social, não há como se fazer uma distinção entre a ordem pública interna, protegida pelas leis cogentes do país, e uma outra ordem pública que só tivesse definição e presença nas relações internacionais".

Desta forma o parecer do Professor Humberto Theodoro Jr, não refletiu a verdadeira posição doutrinária sobre os dois efeitos diferentes da ordem pública.

O parecer invoca Amilcar de Castro, mas, em verdade, este mestre deixou claramente delineado a distinção, ao dizer, em trecho já acima reproduzido.

“...mas como pode (a ordem pública) ser agredida de dois modos, por ataques prove- 
nientes de situações diversas, é sempre defendida por duas formas .... Diferença se encontra nos meios de defesa da ordem pública ..."

O parecer apresentado pelos Embargantes sobre o princípio da ordem pública conclui da seguinte forma:

"Vê-se, então, que a ordem pública é una e indivisível e tanto pode ser agredida nas relações internas como nas internacionais. A reação da soberania nacional é sempre a mesma: nega eficácia ao ato violador e faz prevalecer a lei de ordem pública interna. Em suma o artigo 17, da LICC, é a fonte irrecusável de prevalência da ordem pública interna quando tenha de dar-se aplicação a direito estrangeiro em nosso território...."

Concordamos que a ordem pública é "una e indivisível";

Estamos de acordo que ela tanto pode ser agredida nas relações internas como nas internacionais.

Mas não se pode dizer que a "reação da soberania nacional é sempre a mesma" porque não é, como vimos acima, com base na doutrina nacional e estrangeira. A ordem pública tem um raio de defesa muito mais amplo em matéria de direito interno do que no campo do direito internacional. A ordem pública pode rejeitar uma manifestação de vontade no plano interno e aceitar uma lei estrangeira que estabeleça exatamente o mesmo. $O$ grau de tolerância no segundo caso é muito maior do que no primeiro.

Observe-se que no código civil brasileiro não há uma regra expressa sobre a ordem pública. Ela é um principio imanente em todo nosso sistema jurídico, diversamente do que propôs Haroldo Valladão no artigo 12 de seu projeto. Já o artigo 17 da Lei de Introdução ao código civil brasileiro só se aplica a matéria internacional e neste contexto estabelece claramente a inaplicabilidade do direito estrangeiro quando o mesmo for incompatível com a ordem pública brasileira.

Isto, em verdade, tem relação com a essência do direito internacional privado, pois se a ordem pública funcionasse com o mesmo rigor no campo internacional do que no campo interno, teríamos que todas as regras que fossem diversas na lei estrangeira em matéria indisponível, não poderiam ser aplicadas no Brasil, porque estariam contra nossa ordem pública. Ora, se a lei de introdução ordena, em caso de conflito de leis, a aplicação de leis estrangeiras em matérias de capacidade e de família (LICC, art. $7^{\circ}$ ), cujas regras são em sua maioria sobre matérias indisponíveis, onde a vontade das partes, se diversa da regra disposta, não é aceita, como então aplicar leis estrangeiras diferentes das nossas? Fica, assim, evidenciado, que diverso é o raio de aplicação do princípio da ordem pública nos dois planos.

Esta distinção do funcionamento da ordem pública no plano interno e no plano internacional irá repercutir de forma manifesta e acentuada na questão da prescrição, o ponto central da consulta.

\section{II PRESCRIÇÃO-PRAZOS PRESCRICIONAIS-DIREITO INTERNO E DIREITO INTERNACIONAL PRIVADO}

Há duas citações feitas pelo Professor Humberto Theodoro Jr. a que gostariamos de aludir: Orlando Gomes, depois de afirmar sobre a prescrição ser " incontestável a natureza de instituto de ordem pública", enumera três consequiências, as primeiras duas que os particulares não podem declarar imprescritível qualquer direito e que a prescrição, antes de consumada, é irrenunciável, e - aqui o ponto de nosso interesse - "os prazos prescricionais não podem ser dilatados pela vontade dos particulares" ( $7^{\mathbf{2}}$ página do Parecer do Professor Humberto Theodoro). A mesma lição se encontra em Silvio Rodrigues, igualmente reproduzida pelo parecer, em sua $8^{\circ}$ página, no sentido de que "as normas sobre a prescrição são de ordem pública, insuscetíveis, portanto, de serem derrogadas por convenção entre os particulares". E depois de citar dois autores estrangeiros que dizem aproximadamente $o$ mesmo, conclui o nobre parecerista com a seguinte afirmação:

"Diante do exposto, forçoso é concluir que, no âmbito do direito internacional privado, a prescrição se insere entre aqueles casos em 
que o direito estrangeiro não pode afastar a vigência da lex fori (LICC, art. 17)".

Data máxima vênia, o parecer colocou uma premissa errônea, daí ter chegado a uma conclusão equivocada.

A premissa errônea - examinada na seção I acima - é a de que a ordem pública teria o mesmo efeito no campo internacional do que no campo intemo.

A conclusão equivocada é que, sendo assim, o que os autores dizem sobre convenção entre os particulares também se aplicaria à lei estrangeira, ou seja, se as partes não podem ampliar prazo prescricional, também e igualmente não se pode aplicar uma lei estrangeira cujo prazo prescricional seja mais longo do que o nosso.

Pretendo demonstrar que isto não é assim.

Demonstrarei inequivocamente que:

I) a prescrição se rege pelo mesmo direito que governa o contrato,

II) lei estrangeira estabelecendo prazo prescricional mais longo que o nosso não fere a ordem pública brasileira.

Esta demonstração será efetuada por meio dos seguintes pontos:
A) Nosso Direito Positivo
B) Direito Internacional Convencional
C) Antecedentes Históricos do Direito Bra-
D) Doutrina Brasileira
E) Direito Estrangeiro sileiro

\section{A) Nosso Direito Positivo-:}

- Código de Bustamante, ratificado pelo Brasil, pelo Decreto 18.871 em 13 de agosto de 1929, dispõe em seus artigos 229, 23 e 295:

Art. 229- A prescrição extintiva de ações pessoais é regulada pela lei a que estiver sujeita a obrigação que se vai extinguir.

Art. 230- A prescrição extintiva de ações reais é regulada pela lei do lugar em que esteja situada a coisa a que se refira.

Art. 295- A prescrição das ações originadas em contratos e atos comerciais ajustar-se-ão às regras estabelecidas neste Código, a respeito das açōes cíveis.

A Lei de Introdução ao Código Civil Brasileiro só determina, em seu artigo $9^{\circ}$, que as obrigações se regem pela lei do país em que se constituírem. Nada sobre a prescrição. Esta lacuna da lei é preenchida pelo Código de Bustamante que é categórico sobre a aplicação da lei do contrato para o tema da prescrição. E o Código de Bustamante é aplicado no Brasil para todas as relações jurídicas, não só para aquelas com os demais signatários do mesmo, mas também para as relaçōes juridicas com paises que sequer assinaram o Código. Daí ser ele denominado de Código. Aliás, não faria sentido que a prescrição fosse regida pela lex loci actus em um caso e pela lex fori em outro caso.

- Convenção de Genebra Destinada a Regular Certos Conflitos de Leis em Matéria das Letras de Câmbio e Notas Promissórias e Protocolo, promulgada no Brasil pelo Decreto 57.663 de 24 de janeiro de 1966.

Art. 5- Os prazos para o exercício do direito de ação são determinados para todos os signatários pela lei do lugar de emissão do título.

Destes dispositivos resulta:

1) que não qualificamos prescrição como matéria processual,

2) que a prescrição é regida pela lei que governa o título - lex loci actus;

3) que a prescrição não é protegida pela ordem pública, daí nada nas Convençōes sobre regência da prescrição pela lex.fori.

B) Direito Internacional Convencional :

- Tratado de Direito Civil Internacional Montevidéu - 1889

Art. 51 - La prescripción extintiva de las acciones personales se rige por la ley a que las obligaciones correlativas están sujetas.

- Tratado de Direito Civil Internacional Montevidéu - 1940

Art. 51 - La prescripción extintiva de las acciones personales se rige por la ley a que las obligaciones correlativas están sujetas.

- Convenção Européia sobre Lei Aplicável às Obrigaçōes Contratuais, Roma - 1980

Art. 10 .

1 - A lei aplicável ao contrato por força dos Artigos 3 a 6 e 12 desta Convenção será aplicada principalmente:

d) às várias formas de extinção das obrigações e à prescrição;

- Convenção Interamericana sobre Lei Aplicável a Contratos Internacionais, México - 
1994, assinada (mas ainda não ratificada) pelo Brasil

Art. 14 - A lei aplicável ao contrato em virtude do capítulo 2 desta convenção regerá principalmente:

d) as várias maneiras pelas quais as obrigações podem ser cumpridas e a prescrição.

- Convenção da Haia sobre Acidentes Rodoviários de 1971

Art. 8 - A lei aplicável determinará, principalmente:

8) regras sobre a prescrição

- Convenção da Haia sobre Responsabilidade pelos Fatos de Produtos de 1973

Art. 8-A lei aplicável por esta Convenção determinara principalmente:

9) regras de prescrição

Convenção da Haia sobre Lei Aplicável aos Contratos de Venda Internacional de Produtos - 1986

Artigo 12 - a lei aplicável ao contrato de venda por força dos Artigos 7, 8 e 9, governará, principalmente:

g) as várias maneiras de extinção das obrigações bem como a prescrição

Qual o interesse em invocar todas estas convençōes? Aqueles que se dedicam ao direito internacional conhecem a importância que deve ser atribuída aos diplomas legais internacionais para as questões que envolvem o direito de mais de um sistema jurídico, mesmo quando estes diplomas não contaram com a participação do país do foro. Quem explica isto, em lição magistral, é Henri Batiffol, o grande mestre do direito internacional privado da Europa nas decadas de 40 a 80 . Em trabalho publicado na Revue Critique de Droit International Prive de 1981, à p. 244 diz o mestre:

"Temos experiência que um trabalho de qualidade sempre exerce influência, mesmo se não adquire a forma de um tratado obrigatório há convenções da Haia que foram aplicadas por tribunais em países que não as haviam ratificado. Quando os juízes não encon- tram em seu sistema jurídico nacional uma resposta adequada para um problema que lhes é colocado, mas vislumbram a solução em uma convenção ainda não ratificada ou ainda não vigente, pode-lhes parecer natural considerar esta resposta como conveniente e justa. E o fenômeno é observado na América Latina com relação à convenção não ratificada por certos Estados, especialmente o famoso Código Bustamante. Em outras palavras, um trabalho bem feito pode exercer uma influência positiva ....."

Esta é uma das páginas mais importantes do modemo direito internacional privado, que tem inspirado juristas e juízes de muitos países. No Brasil certamente existe uma atitude extremamente positiva em relação às convenções que não foram por nós ratificadas ou sequer assinadas, como atestam inúmeros acóı Jãos da Suprema corte brasileira em que decisões foram construídas corn fundamento em princípios e regras fixados nas Convenções da Haia.

C) Antecedentes Históricos do Direito Brasileiro

Lafayette Rodrigues Pereira em seu projeto estabeleceu a seguinte regra

Art. 65 - A prescrição extintiva é regida pela lei que regula a obrigação.

O Projeto de Código Civil de Clovis Bevilaqua, na introdução, continha a seguinte regra:

Art. 21: A prescrição extintiva é regida pela lei do lugar em que se originou a obrigação, e o usucapião pela da situação dos bens.

Informam Eduardo Espínola e Eduardo Espínola Filho, Tratado de Direito Civil Brasileiro, vol. VIII, p. 608, nota j, que tal dispositivo foi conservado pela Comissão Revisora e aprovado pelo Parecer do Relator Deputado Azevedo Marques. Mais tarde, no entanto, quando do parecer para votação do título preliminar, o mesmo relator já não incluiu o preceito, que não veio a figurar no substitutivo Andrade Figueira.

Argumentou Andrade Figueira:

"Propositalmente não tem tratado da prescrição, de que se ocupa o projeto. A prescrição ou é um meio de extinguir direito e obrigações, é prescrição extintiva, ou é um modo de 
adquirir a propriedade. Ora, como meio de extinguir direitos, nada tem de diferente dos outros meios de extinguir direitos e, se formos criar uma lei de direito internacional privado para a prescrição extintiva, devemos criar pra todos os meios de extinção de direito, como pagamento e outros. Não há necessidade. A mesma lei que rege o contrato rege-o em todas as suas dependências: rege a prescrição, como todos os outros meios extintivos, como o pagamento etc... Em resumo, se se trata de prescrição extintiva, ou de direito pessoal, como meio de extinção, o que se atende é a obrigação, que se extingue para uma parte e que nasce para outra; portanto, é o direito pessoal da obrigação .... Sabe que os novos tratadistas dissertam largamente sobre a prescrição mas acha que com este sistema está resolvida a dificuldade. O projeto manda que a prescrição extintiva siga a lei do contrato e quanto aos bens manda que siga a lei da situação. É o que está estabelecido na emenda."

Vemos, assim, que o legislador brasileiro simplesmente considerou supérflua uma regra sobre a prescrição, urna vez que esta se rege automaticamente pela mesma lei que rege o contrato no plano internacional.

D) A Doutrina Brasileira

Clóvis Bevilaqua em seu clássico Principios Elementares de Direito Internacional Privado, à pagina 275 assim escreveu

"Mas,como a prescrição extingue a ação, fere o direito em um de seus elementos, deve depender da mesma lei que preside a existência do direito, isto é, da lei que preside a formação do vínculo obrigacional ou a constituição do direito defendido pela ação que se trata de saber se está ou não prescrita."

À página 276 informa Clovis:

"Frankenstein estabelece a respeito da prescrição alguns princípios que é de interesse consignar, em rápido resumo.

Teoricamente, diz ele, é difícil qualquer dúvida. Se todo direito subjetivo está sujeito à mutabilidade do tempo, no qual nasce e morre, traz em si, ao nascer, o germen da sua extinção pela prescrição. Daí resulta o seguinte postulado científico: a prescrição rege-se pela lei a que o direito está submetido.
Na Alemanha, Áustria e Suíça, a literatura e a jurisprudência seguem este princípio".

(Em seguida faz referência ao direito angloamericano, onde prescrição é considerada matéria processual e alude à concepção francesa de que a prescrição tem caráter de ordem pública. Mais adiante, no presente parecer, veremos que a doutrina e a jurisprudência francesas modificaram totalmente sua posição).

Pontes de Miranda trata da matéria em seu Direito Internacional Privado, vol. I, pp. 546554. Defende, em sua linguagem obscura e confusa, que a prescrição é regida pela mesma lei que rege a obrigação e não pela lex fori. Assim, à pagina 547 , sob $n^{\circ} 2$ :

"Qual a lei que rege a prescrição? A questão deve ser posta, preliminarmente, no terreno das competências legislativas. Fora daí, tudo será discussão no domínio do Direito Intemacional Privado de cada país, sem solução $a$ priori possível."

página 548, último parágrafo:

“.... A simples exposição mostra que as três classes são inúteis: existe a lei única da prescrição, que é a competente para reger o negócio."

página 550 , sob n 3 :

"A ordem jurídica a que pertence o direito é a que regula a prescrição" portanto, o estatuto da pessoa, ou o da coisa. Coincide tal. princípio de competência com o sistema de Direito Internacional Privado de muitos países, como a Alemanha, a Áustria, a Suiça, o Brasil. Diferente é o que adota o Direito anglo- americano. Em vez de ser de direito material, é de direito processual a prescrição, aqui, não extingue a ação, mas só o remédio. página 552 sob $n^{\circ} 6$ :

"Alguns Estados consideram de ordem pública vários artigos de lei sobre prescrição, procedimento que raro se justifica, Outras vezes, um Estado considera imprescritível o que outro tem por prescritível .... No Brasil, nenhuma distinção se faz quanto a ser mais curto o prazo da lex.fori, e o art. 165 do Código Civil obsta a que os juízes pensem em que a prescrição civil é de ordem pública".

Oscar Tenório, Direito Internacional Pri- 
vado, vol. 2 , versa a matéria nas pp. $215 \mathrm{e}$ segs. À p. 222, nº 951 diz,

"Procurando através do direito comparado a interpretação do direito brasileiro, podemos concluir que a matéria da prescrição liberatória ou extintiva está compreendida na regra do art. $9^{\circ}$ da Lei de Introdução ao Código Civil, onde se diz que para qualificar e reger as obrigações, terá aplicação a lei do país em que se constituírem. É, para empregarmos a linguagem de Savigny, a lei da sede da obrigação que determina a prescrição.

No direito brasileiro, onde não há disposição expressa, os termos qualificar' e 'reger' podem ser entendidos como abrangendo a prescrição."

Haroldo Valladão também sustenta que a prescrição extintiva se rege pela mesma lei que regula a substância do ato (art. 31 do seu Anteprojeto), tendo acrescentado que a prescrição deverá ser decretada no Brasil se atingir o prazo da prescrição ordinária da lei brasileira (Anteprojeto, art. 31, parágrafo único), ou seja, nas condiçôes atuais da lei brasileira, se o decurso de prazo alcançar vinte anos, não se poderá mais esperar e a prescrição deverá ser decretada. Valladão explica à página 36 do volume II de seu Direito Internacional Privado:

"Impunha-se esse limite, pois a prescrição ordinária ou comum, o prazo máximo estabelecido pela lei do foro, é sempre de ordem pública, visando à paz social definitiva, correspondendo à praescriptio longissimi temporis".

Para Valladão, no presente caso, se a lei novaiorquina estabelecesse um prazo prescricional mais longo do que vinte anos, não deveríamos ir além deste prazo máximo de nossa legislação, porque seria contrariar nossa ordem pública aceitar uma lei que contivesse prazo de prescrição cambiária mais longo do que nosso prazo mais estendido.

Wilson de Souza Campos Batalha tem a mesma posição. Veja-se em seu Direito Internacional Privado, vol. II, p. 199:

"A aplicabilidade do estatuto da obrigação parece-nos fora de dúvida, pois a prescrição constitui modalidade de extinção das obrigações; só se poderia cogitar da incidência da lex fori em sistemas nos quais, como o angloamericano, a prescrição constitui exclusivamente instituto de direito processual e não de direito material. Ressalve-se, naturalmente, a ordem pública do foro, por exemplo, nas hipóteses de direitos imprescritíveis."

Em trabalho recentemente publicado na Texas International Law Journal, volume 33 pp.425-461 (1998), escreveu o presente parecerista, de parceria corri a Professora Carmen Tiburcio, à p. 432:

"Statutes of limitation are equally outside the domain of the procedural law of the forum because they concern the ability to enforce the right in question. Therefore, statutes of limitation are subject to the same rule of law as lhe main subject of the case. Thus, the statute of limitation regarding a suit for the annulment of an act is regulated by the same la.. that regulates the act itself."

ou seja

"As regras sobre prescrição estão igualmente fora do alcance da lei processual do foro porque dizem respeito à faculdade de fazer valer o direito em discussão. Por isto a prescrição está sujeita ao mesmo sistema jurídico do que a matéria principal do caso. Decorre que a prescrição relativa a uma ação que visa a anulação de um ato é regida pela mesma lei que regula o próprio ato".

Vemos que a doutrina brasileira de Direito Internacional Privado é unânime quanto à aplicação da lei que rege a substância do ato para a prescrição, não reconhecendo qualquer incompatibilidade com nossa ordem pública em aplicar um prazo prescricional mais longo do que o previsto no direito positivo brasileiro.

E) Direito Estrangeiro

\section{França}

No passado a jurisprudência francesa entendia beneficiar o devedor caso a lex fori lhe fosse mais vantajosa quanto ao prazo prescricional. Mas em 1960 alterou-se a jurisprudência com uma decisão publicada na Revue Critique de Droit International Privé de 1960, p. 202 , no sentido de que a prescrição é regida pela lei que rege o contrato, confirmando-se este critério em 1971 por dois acórdãos da Corte de Cassação que afirmaram que a 
“prescrição extintiva de uma obrigação fica submetida à lei que rege a mesma".

Comentando esta jurisprudência dizem Batiffol e Lagarde, no volume II de sua já acima referida obra, à p. 352 , sob $n^{\circ} 615$ :

"Esta solução parece bem fundamentada. Efetivamente, se a prescrição protege o devedor .... ele parece suficientemente protegido pela lei do contrato, cujas disposições ele conhecia..."

Pierre Mayer, em "Droit International Pri$v e ̂$ ', $5^{a}$ edição, 1994, à p. 487 escreve

"As causas de extinção que consistem em simples fatos jurídicos são submetidas à lei que rege a obrigação (lei do contrato em caso de obrigação contratual, lei do delito em caso de obrigação delitual etc.). $\mathrm{O}$ mesmo se aplica à prescrição ..."

Dominique Holleaux, Jacques Foyer e Géraud de Geouffre de La Pradelle, em obra conjunta Droit international privé, 1987, dizem à p. 400 :

“Modo de extinção da ação, a prescrição é diretamente ligada ao direito cuja sanção judiciária ela paralisa. Deve, portanto, ser submetida à lei que rege este direito e não ao direito do foro (cf. Hage-Chahine, Les conflits dans l'espace et dans le temps en matière de prescriptions, Paris, Dalloz 1977, nº 284 s. p. 187 s.)".

O famoso caso Patino é ilustrativo. Maria Cristina de Bourbon, espanhola, assinou em 1931, com 18 anos de idade, um contrato ante nupcial com Antenor Patiño, boliviano, e com o casamento a jovem adquiriu a nacionalidade boliviana. Em 1955 Maria Cristina ingressa em corte francesa com ação para declarar a nulidade do contrato ante nupcial pois era menor à época em que o firmou. O prazo prescricional pela lei espanhola era de 30 anos, portanto estava ela dentro do prazo. Mas pela lei boliviana, sua nacionalidade atual, $o$ prazo era de 10 anos e a ação estava prescrita. $O$ debate entre as partes travou-se exatamente sobre qual lei seria aplicável ao prazo prescricional: lei espanhola ou lei boliviana. A Corte de Cassação francesa decidiu pela aplicação da lei espanhola, que era a lei pessoal da autora à época em que firmou o contrato, para o qual, segundo sua lei pessoal de então, era incapaz.

Comentando esta decisão, o mestre belga François Rigaux, no V volume de seu Droit International Privé, 1977, p. 383, diz o seguinte:

“.... a câmara civel (da Corte de Cassação) sublinhou a conveniência de não disassociar a prescrição da incapacidade originária em que a ação de nulidade se baseava. A mesma conveniência que justifica a aplicação da lei da obrigação quando esta concorre com a lex fori".

Em outras palavras, o prazo da prescrição em ação fundada na incapacidade do agente se rege pela lei pessoal do agente e o prazo da prescrição em ação fundada em contrato se rege pela lei do contrato. Nunca pela lei do foro.

\section{Bélgica}

François Rigaux, o mestre do direito internacional privado belga na obra já referida, vol. 1 , p. 339 . assim coloca:

“... parece justo submeter a obrigação aos prazos prescricionais previstos na lei que a rege, restringindo o domínio da lex fori ......"

\section{Inglaterra}

Em Cheshire and North's Private International Law, 12a edição, 1992, lemos:

"O segundo tema é o da prescrição e limitação de ações, que também é submetida à lei aplicável como determinado pela Convenção (Roma, 1980, acima referida). Este dispositivo foi em parte responsável pela recente mudança na lei inglesa sobre limitação de ações. Antigamente a questão da prescrição era vista pelo direito inglês como matéria processual a ser decidida pela lei do foro. No entanto, o Foreign Limitation Periods Act 1984 mudou a regra adotando o princípio que o tribunal inglês deve aplicar à prescrição a lei que governa a matéria substantiva de acordo com as regras conflituais do direito inglês. Assim, mesmo antes da Convenção de Roma entrar em vigor na Inglaterra, o direito inglês sobre prescrição produziu o mesmo efeito em casos de contratos como presentemente ocorre por força do artigo 10 (1) (d)". 
Alemanha

O EGBGB Introdução ao código civil alemão - conforme reforma produzida em 1986 é preciso a respeito de nosso tema, dispondo o artigo 32 que a lei aplicável ao contrato, na conformidade dos artigos 27 a 30 e 33, parágrafos 1 e 2 rege, entre outras matérias, as várias maneiras de extinção das obrigações e a prescrição.

\section{Canadá}

O código civil de Quebec, reformado na parte relativa ao direito internacional privado, dispõe no lacônico artigo 3.131 que a prescrição é regida pela lei que se aplica à substância do litígio.

\section{Peru}

O código civil do Peru, artigo 2.099 determina que a prescrição extintiva das ações pessoais é regida pela lei que se aplica à obrigação que vai ser extinta.

\section{Portugal}

Artigo 40 do código civil português: “A prescrição e a caducidade são reguladas pela lei aplicável ao direito a que unia ou outra se refere".

\section{Suiça}

Nova lei suiça de direito internacional privado, 1987, artigo 148. 1- "A lei aplicável à demanda governa a prescrição e a extinção",

\section{Turquia}

Lei de DIP de 1982, artigo 7 - “A prescrição é submetida à lei que rege a substância do ato e da relação jurídica".

\section{Itália}

A recente lei italiana sobre o direito internacional privado, de 1995 , artigo 57 , submete as obrigações contratuais à Convenção de Roma de 1980, que, como já visto acima, tem dispositivo expresso sobre a aplicação da lei contratual à matéria da prescrição.

Vemos, assim, que as legislações aqui reproduzidas, ilustrativamente, subordinam a prescrição à lei que rege a substância do ato em questão e nenhuma delas faz qualquer ressalva de ordem pública à plena aplicação da lei contratual.

III

\section{QUALIFICAÇAO DA PRESCRIÇÃO}

Sustenta o Professor Humberto Theodoro Jr. em seu Parecer que por ser a prescrição um instituto processual nos Estados Unidos, diversamente do que ocorre no Brasil, não podemos em tribunal brasileiro aplicar a lei americana sobre prescrição.

Antes de examinar a tese do ilustre parecerista, há de ser referido o trecho que o mesmo transcreveu de Irineu Strenger em que o professor paulista se refere à crítica de Frankenstein a uma decisão de tribunal alemão que este jurista tedesco considerou equivocada. Tratava-se de uma execuçao cambiária constituída nos Estados Unidos e processada na Alemanha em que o réu invocava em sua defesa a prescrição da dívida, de acordo com ambas as leis, a americana e a alemã. Como a lei aplicável era a americana - local da constituição da obrigação - mas como nos Estados Unidos prescrição é matéria processual, o tribunal rejeitou a defesa, porque a prescrição pela lei alemã não ajudava o réu, eis que a lei alemã era incompetente, e a lei competente, a americana, não podia ser aplicada porque ela qualifica a prescrição como instituto processual.

Frankenstein considera - com toda razão - que a corte alemã errou, lendo-se em Strenger a seguinte colocação transcrita pelo parecerista, como se ela lhe desse algum apoio:

"Consequientemente, se uma questão de acordo com o conceito de direito germânico é de direito substantivo e segundo a concepção estrangeira é direito processual, o direito alemão não poderia submeter seus nacionais ao direito americano e o juiz deveria resolver a questão de acordo com sua própria lei."

O significado deste trecho é de que o mesmo versa a matéria da qualificação, ou seja não podia o juiz submeter seus nacionais à qualificação do direito americano que considera prescrição matéria de direito processual mas deveria resolver a questão de acordo com a qualificação de sua própria lei. 
É o que Irineu Strenger diz logo adiante: “A lei que for aplicável às pessoas e às coisas deve determinar suas próprias qualificações $\mathrm{e}$ o valor de seus termos". E conclui o ilustre professor da Universidade de São Paulo: "Frankenstein queria demonstrar é que não se pode ser absolutamente rigoroso dentro da lex causae em detrimento da questão que pode ser nacional. Por esta circunstância deve-se acender (atender) também à lex fori".

Em outras palavras, o tribunal alemão deveria ter qualificado a prescrição pela lei do foro e aplicado o prazo prescricional estabelecido na lei americana.

É o que deve ocorrer igualmente no caso em espécie entre o Banco do Brasil e os avalistas da Mendes Junior: a qualificação da prescrição - direito processual ou substantivo - é da competência da lex fori, enquanto que a prescrição propriamente dita, ou seja o prazo prescricional, é regido pela lei americana, que rege as notas promissórias.

Amilcar de Castro coloca a qualificação dos institutos pela lex fori, assim se pronunciando na obra já acima citada, respectivamente às pp. 212,213 e 214 :

"O que parece razoável é que, na escolha da norma de direito internacional privado, sempre se leve em consideração a qualificação do direito primário indígena (ius fori).

“As qualificações de que se utiliza o direito internacional privado são sempre as mesmas de que se serve o direito primário, pois são dadas pela ordem jurídica, para todos os seus setores."

"Em suma: as qualificações utilizadas na escolha da norma de direito internacional privado só podem ser dada pelo ius.fori; e são sempre únicas em cada ordem jurídica".

Note-se que o Código de Bustamante é enfático quanto à qualificação pela lei do foro. Em seu artigo $6^{\circ}$ dispõe:

Art. $6^{\circ}$ - Em todos os casos não previstos por este Código, cada um dos Estados contratantes aplicará a sua própria definição às instituições ou relações Jurídicas que tiverem de corresponder aos grupos de leis mencionados no artigo $3^{\circ}$.

No caso objeto do presente Parecer a qualificação da prescrição é do foro, da lei brasi- leira. A lei aplicável é a que rege a relação cambiária, onde as promissórias foram assinadas e avalisadas - lei de Nova York aplicando-se-a também para efeitos do prazo prescricional.

A técnica do direito internacional privado é aplicar o direito estrangeiro naquilo que ele é aceitável e rejeitá-lo naquilo que é incompatível com o direito do foro.

Um exemplo clássico de como se aproveita tudo aquilo que disposto na lei estrangeira que não seja atentatório à nossa ordem pública é a famosa decisão da corte suíça que julgando matéria submetida à lei alemã, descobre que segundo este direito, o direito em causa era imprescritível. Isto, considerou o tribunal suíço, era totalmente inaceitável pelo direito helvético, por ser contrário à sua ordem pública. Havia que estabelecer a prescrição; por qual prazo? Decidiu a corte que ao invés de aplicar o prazo prescricional suíço, aplicaria o mais longo prazo prescricional do direito alemão, para aplicar este direito até onde possível, só rejeitando a aplicação do direito alemão naquilo que absolutamente necessário. (RG 19 dezembro 1922, RGZ 106, 85, conforme citado em Rigaux, op. cit., p. 353.)

Desta forma, assim como uma norma legal estrangeira que seja chocante à nossa ordem pública não é aplicável em nosso território, mas só naquilo que seja incompatível com nosso direito, admitindo-se aplicar as demais regras do sistema jurídico estrangeiro que não contenham atentado a nossa ordem pública, assim também as qualificações do direito estrangeiro, que são diferentes das nossas, não são por nós aceitas, sem prejuízo da aplicação da norma material da legislação estrangeira.

\section{$\mathrm{V}$ \\ RESUMO DAS PRINCIPAIS QUESTÕES ABORDADAS NO PARECER}

1. Não há que se falar em duas ordens públicas distintas, pois o Estado só pode ter uma ordem pública que é interna, nacional. A distinção se dá no plano dos efeitos: um efeito se dirige ao plano interno do direito, o outro vai além e, na defesa da mesma ordem pública 
interna, barra a entrada de normas, vontades e sentenças estrangeiras,,

2. A ordem pública tem um raio de atuação muito mais amplo em matéria de direito interno do que no campo do direito internacional. A ordem pública interna pode rejeitar um ato praticado no Brasil e aceitar uma lei estrangeira que estabeleça exatamente o mesmo. O grau de tolerância no plano internacional é muito maior do que no plano interno.

3. As normas sobre prescrição no direito brasileiro são normas imperativas e, portanto, inderrogáveis pela vontade das partes (ordem pública no direito interno).

4. Diversa a situação no plano internacional, onde a prescrição não constitui matéria de ordem pública, daí nenhum obstáculo à aplicação no Brasil de prazos prescricionais do direito estrangeiro, mais longos do que nossos prazos.

50 direito convencional em vigor no Brasil - Código Bustamante e Convenção de Genebra - qualifica a prescrição como matéria de direito substantivo, sendo regulada pela lei que governa o ato - lex loci actus - e não atribui à matéria qualquer conotação de ordem pública no plano internacional.

6. Outras convenções, elaboradas sob os auspícios da CEE, da OEA/Cidip, da Conferência da Haia, dentre outras, também seguem esta orientação: a prescrição é matéria substantiva a ser regida pela lei que rege a substância do ato ou contrato e não constitui questão de ordem pública no direito internacional privado.

7. Os antecedentes históricos do direito brasileiro sempre consideraram a prescrição extintiva como regida pela lei que regula a obrigação.

8. A doutrina brasileira de direito internacional privado, na sua unanimidade, defende que a prescrição extintiva deve ser regida pela mesma lei que rege a substância do ato e entende que a ordem pública no direito inter- nacional não impede a aplicação de lei estrangeira que estabeleça prazo diverso daquele fixado pela lei brasileira.

9. $O$ direito da França, Bélgica, Inglaterra, Alemanha, Canadá, Peru, Portugal, Suíça, Turquia e Itália, entre muitos outros, adotam este mesmo entendimento.

10. A qualificação dos institutos é sempre determinada pela lex fori. A qualificação estrangeira diversa da nossa não impede a aplicação de sua norma material.

\section{VI \\ CONCLUSÕES}

Em síntese, a presente situação, em conformidade com a legislação em vigor no país e a unânime opinião da doutrina, deverá ser solucionada da seguinte forma:

1. No direito positivo brasileiro o instituto da prescrição é qualificado como direito material e não como direito processual,

2. A qualificação dos institutos jurídicos é determinada pela lex.fori. Assim deve aplicarse à prescrição a qualificação do instituto adotada pela lei brasileira - direito material;

3. O direito brasileiro - legislação e doutrina - subordinam a prescrição à mesma lei que rege a substância do ato, no caso presente a lei novaiorquina;

4. Não fere a ordem pública do direito internacional privado brasileiro a aplicação de lei estrangeira que estabeleça prazo prescricional mais longo daquele adotado na lei brasileira,

5. Assim, o prazo prescricional aplicável à hipótese é o determinado pela lei de Nova York - seis anos.

S.M.J.

Rio de Janeiro, 13 de Outubro de 1999, Jacob Dolinger

Professor de Direito Internacional Privado da Universidade do Estado do Rio de Janeiro. 